\title{
Food safety challenges associated with traditional foods of Turkey
}

\author{
Arzu CAGRI-MEHMETOGLU ${ }^{1 *}$
}

\begin{abstract}
Consumer food safety concerns are continually increasing in Turkey, with consumer demand for safer foods becoming an important challenge for the industry. Most traditional foods in Turkey are produced under different requirements, and food safety risk management and risk assessment are conducted primarily by the government. Based on risk assessment, safety regulations and standards for traditional foods (e.g. Turkish white cheese, doner, helva) have been established. In this paper, safety concerns surrounding the commercialization of traditional Turkish foods and related studies to identify and minimize potential hazards are discussed along with pathogen contamination in raw meat balls and aflatoxin in helva and white cheese. Based on this review, additional national risk analysis experts and related databases are urgently needed. In addition, the manufacturing processes for traditional foods need to be standardized and harmonized with international standards, such as CODEX.
\end{abstract}

Keywords: traditional foods; safety; risk assessment; Turkey.

Practical Application: This study has analyzed the risks of consumption of traditional foods produced in Turkey. The results of this work will be applied in the regulation of the legislation and in the monitoring of the safety of traditional foods. This will reduce the risks that threaten people in the production of these foods.

\section{Introduction}

Local products are referred to as traditional products, the boundaries of a particular geographical area, which are linked to a particular region's cultural traditions. Turkey is among the richest countries in terms of food and drink culture (Albayrak et al., 2013; Erkmen \& Bozoğlu, 2016). The importance of traditional food is increasing both at the national and international markets due to changes in consumers' lifestyles, including their demand for new flavors, new products, safe and less processed foods.

Consumption of traditional foods in Turkey with rich and important advantages in terms of traditional products, it is important to evaluate the use and degradation of these products correctly. In Turkey, important challenge is that production of traditional foods should not be restricted to small amounts and certain regions. Adapting traditional foods to industrial production without changing their characteristics and compromising their taste and appearance is very demanding and with identifying essential criteria, and creating appropriate legislation on this issue (Erginkaya et al., 2014). Therefore, as the whole world today, our country is facing inevitable legislation difficulties regarding traditional foods.

Incentive policies should be established to ensure the industrial production of traditional food in the original region. In developed countries, the rules determined by the scientific methods are issued in order to produce food products with regional and the traditional characters at best and safe way. In Turkey, the creation of such a system at scientific and legal base and controlling and monitoring of the system by certain authorities are very essential for the promotion of our products.
In recent years, due to increased consumer sensitivity to food production and consumption, not only traditional foods in all food demand determinants of food security, which has become one of the items on the agenda. Food safety, after food production in general consumption (from farm to fork) until the chemical, physical, sensory and presented to the consumer in a healthy and reliable manner while preserving the biological properties and covers the package of measures taken for this purpose. However, the legislation is also harmful to health food and acceptable level of risk foods are defined as safe food. In this review, epidemiological data and scientific studies were collected and investigated in order to analyze the safety risk of some traditional foods in selling Turkey associated with microbiological contaminants. Traditional foods focused in this review were chosen by considering regarding research intensiveness. They include raw meat ball, doner kebab, midye dolma (stuffed mussel), kokorec, tahin helva and white cheese, all which may pose a public health risk will now be reviewed.

\section{Traditional Turkish foods and their microbiological safety}

\subsection{Raw meat ball (cig kofte)}

Raw meat ball (cig kofte) usually composed of ground beef, bulgur, tomato paste, paprika, black pepper, onion, parsley and salt in a specific proportion (Ocal, 1997; Uzunlu \& Ylldırım, 2003). This blend is hand-kneaded with water to achieve the 
desired consistency. Raw meat ball is consumed as a starter mainly during folk music gatherings in South-Eastern Anatolia. Recently, it has also been commercially accessible in markets and restaurants.

No heating step is involved in the production of raw meat ball, making it one of the riskier foods in Turkey. The safety of raw meat ball is determined by the microbial load in the minced meat and spices. Several studies reported the presence of various pathogens including Salmonella spp., Listeria monocytogenes, Staphylococcus aureus, Clostridium perfringens, Escherichia coli O157:H7, Yersinia enterocolitica and Bacillus cereus in minced beef and spice samples collected from Turkish markets (Sancak et al., 1993; Guven et al., 1997; Sagun et al., 1997a; Uzunlu et al., 2002; Yücel et al., 2005; Kimiran-Erdem et al., 2014). For example, Yücel et al. (2005) isolated L. monocytogenes from 9 (6.1\%) of 146 raw meat ball samples and Uzunlu et al. (2002) found that black and red pepper contained $S$. aureus or coliform bacteria at levels of $10^{4}$ or $10^{3} \mathrm{CFU} / \mathrm{g}$, respectively.

Several studies indicated that raw meat ball was microbiologically hazardous for human consumption (Arslan et al., 1992; Sagun et al., 1997b; Uzunlu et al., 2002; Pekel et al., 2003; Kuplulu et al., 2003; Isleyici et al., 2006; Durmaz et al., 2007; Cetinkaya et al., 2012; Delikanlı et al., 2014; Ghazzi et al., 2018). High numbers of $S$. aureus (3 logs CFU/g), Salmonella spp., E. coli O157:H7 (3-4 logs CFU/g), B. cereus (2-4 logs CFU/g), and coliforms (4-5 logs CFU/g) have been detected in raw meat ball collected from several cities in Turkey (Table 1). In addition, $14-34 \%$ of raw meat ball samples collected from markets or restaurants were positive for Salmonella spp., 26-80\% positive for S. aureus, 8-20\% positive for E. coli O157, 5-8\% positive for L. monocytogenes and $40 \%$ positive for B. cereus. Based on these findings, all authors of these studies agreed that much of the raw meat ball produced in Turkey is not suitable for human consumption.

Inevitably, these microbiological populations increase in raw meat ball during unhygienic preparation (i.e., by infected hands and nails) and improper storage (Uzunlu et al., 2002). Preferably, raw meat ball should be consumed within a few hours of preparation and should be refrigerated no longer than 24 h (Göktan \& Tuncel, 1988). The effect of different storage temperatures on pathogen growth in raw meat ball has been investigated with S. aureus $\left(10^{5} \mathrm{CFU} / \mathrm{g}\right)$ surviving and producing enterotoxin $\mathrm{A}, \mathrm{B}, \mathrm{C}$ and $\mathrm{D}$ at temperatures of $10^{\circ} \mathrm{C}$ or higher. (Sagun et al., 2003). L. monocytogenes serotypes $1 / 2 \mathrm{~b}$ and $4 \mathrm{~b}$ $\left(10^{4} \mathrm{CFU} / \mathrm{g}\right), S$. Enteritidis SZH $\left(10^{3} \mathrm{CFU} / \mathrm{g}\right)$ and S. Typhimirium $\left(10^{7} \mathrm{CFU} / \mathrm{g}\right)$ were also able to survive and growth in raw meat ball during $24 \mathrm{~h}$ of storage at $4{ }^{\circ} \mathrm{C}$ (Uzunlu \& Ylldırım, 2003; Durmaz et al., 2007; Guran \& Oksuztepe, 2014). However, in another study no viable cells of $S$. aureus ATCC 6538 were recovered from inoculated raw meat ball after $72 \mathrm{~h}$ of storage at 4 and $25^{\circ} \mathrm{C}$ (Erdoğrul et al., 2006).

Thus far, relatively few outbreaks of foodborne illness have been traced to consumption of raw meat ball in Turkey due to

Table 1. Hazardous in Some Turkish traditional food products for health.

\begin{tabular}{|c|c|c|c|c|}
\hline $\begin{array}{l}\text { Traditional } \\
\text { Foods }\end{array}$ & Ingredients & Pathogens and toxin detected & Associated Outbreaks & Risk analysis \\
\hline Raw meat ball & $\begin{array}{l}\text { Red meat, bulgur, spices } \\
\text { Low pH 4.0, spices, salt }\end{array}$ & $\begin{array}{l}\text { Salmonella spp. (14 - 34\%), } \\
\text { L. monocytogenes }(5-8 \%) \text {, } \\
\text { S. aureus (26-80\%), E. coli } \\
\text { O157:H7 (8-20\%), B. cereus } \\
(40 \%)\end{array}$ & $\begin{array}{l}143 \text { cases, } 5 \text { died in one } \\
\text { outbreak in Gaziantep, Turkey } \\
100 \text { cases associated with } \\
\text { consumption of raw meat } \\
\text { balls made of pork meat } \\
\text { contaminated with Trichinella } \\
\text { spp. in Izmir, Turkey }\end{array}$ & $\begin{array}{l}\text { No cooking involved, low } \\
\text { pH and spices not provide } \\
\text { sufficient protection from } \\
\text { pathogens in fresh meat }\end{array}$ \\
\hline Doner Kebab & $\begin{array}{l}\text { Red meat, poultry, yogurt, } \\
\text { spices }\end{array}$ & $\begin{array}{l}\text { S. aureus }(42 \%), \text { B. cereus, } \\
\text { C. perfringens }(20 \%) \text {, } \\
\text { L. monocytogenes }(18.8 \%) \text {, } \\
\text { E. coli O157:H7 }(11 \%), \\
\text { Salmonella spp }(40 \%)\end{array}$ & $\begin{array}{l}\text { Several outbreaks were } \\
\text { reported in England, Germany, } \\
\text { Turkey, Canada }\end{array}$ & $\begin{array}{l}\text { After cooking storage at } \\
\text { improper temperature and } \\
\text { high possibility of anaerobic } \\
\text { growth and enterotoxin } \\
\text { production }\end{array}$ \\
\hline Tahin Helva & $\begin{array}{l}\text { Sesame paste, sugar, citric } \\
\text { acid, tartaric acid, Saponaria } \\
\text { officinalis root extract }\end{array}$ & $\begin{array}{l}\text { S. Thyphimurium, S. enteritidis, } \\
\text { S. Offa, S. Tennessee, and S. } \\
\text { Poona }(9.4 \%)\end{array}$ & $\begin{array}{l}\text { Total } 72 \text { cases in } 3 \text { outbreaks in } \\
3 \text { countries (Austria, Sweden, } \\
\text { England) }\end{array}$ & $\begin{array}{l}\text { Contaminated ingredients, } \\
\text { unhygienic manufacturing }\end{array}$ \\
\hline Stuffed mussel & Mussel, rice, black pepper & $\begin{array}{l}\text { L. monocytogenes, Vibrio, } \\
\text { B. cereus }(38.69 \%), \text {, S. aureus } \\
(23.80 \%)\end{array}$ & $\begin{array}{l}\text { Not officially reported, few } \\
\text { unofficially reported cases in } \\
\text { newspaper }\end{array}$ & $\begin{array}{l}\text { Prepared unhygienic } \\
\text { conditions, } \\
\text { contaminated ingredients, } \\
\text { postprosessing contamination }\end{array}$ \\
\hline $\begin{array}{l}\text { Fresh white } \\
\text { cheese }\end{array}$ & Unpasteurized milk & $\begin{array}{l}\text { L. monocytogenes (3-13.4\%), } \\
\text { Brucella spp. (20.5\%), Aflatoxin } \\
(62 \%)\end{array}$ & Brucella sourced outbreaks & $\begin{array}{l}\text { Unpasteurized milk, } \\
\text { consuming fresh cheese, sold } \\
\text { in bazaar }\end{array}$ \\
\hline
\end{tabular}


a lack of adequate reporting. In the small town of Gaziantep in southern Turkey, 143 people became ill and 5 died after consuming raw meat ball contaminated with $S$. enteritidis (Cakir, 1991). During a 2004 outbreak in Izmir, Turkey, consumption of raw meat ball prepared using pork meat contaminated with Trichinella spiralis, resulted in the hospitalization of more than 100 people (Karlıkaya et al., 2005).

Application of irradiation was studied as a possible preservation method for raw meat ball (Yildırım et al., 2005; Vural et al., 2006) with these studies reporting that populations of coliform bacteria and E. coli O157:H7 were reduced to below detectable levels using a gamma irradiation of $2 \mathrm{kGy}$. However, S. aureus, Clostridia, yeast and mold could only be inactivated using 3-4 kGy. Given the many constrains associated with irradiation, this method is clearly not feasible for the elimination of pathogens from raw meat ball produced in homes and restaurants.

Commercially production and selling of raw meat ball in restaurants in Turkey were restricted by the food regulations in 2012 due to its stated high contamination risk with food pathogens. After the regulation, instead of using traditional beef or lamb, the meat has been replaced by finely ground bulgur wheat in commercial base. However, this food can be still listed as traditional food carrying safety problems due to continuation of its preparation and consumption in social gatherings.

\subsection{Kokorec}

Kokorec made of seasoned lamb intestines might also create high risk. Kokorec is cocoked in several different ways: one way is to cook kokorec on a horizontal skewer. The intestine fragments are piled together on the skewer in the form of a horizontal roll. Cooked intestine is chopped and consumed with bread. Spices or salad can be added by preferences. Another way to prepare kokorec is cooking chopped intestines with sliced tomatoes, green peppers and spices on a big grill in large quantities.

At the last years, parallel to growing fast food consumption in big cities the consumption of kokorec was also increased. Although a regulation was passed in 2005 regarding microbiological standardization and restriction in kokorec selling in street, due to insufficient inspection, this regulation can be violated in some area (Turkey, 2005c).

Kokorec, one of the traditional foods, is high involving probability in foodborne diseases when the microbiological flora of intestine or low hygienic conditions in production of kokorec was considered. The results of three different studies indicated that kokorec samples collected from the street vendors in Istanbul, Ankara, Bursa, and Afyonkarahisar, Turkey contained $10^{2}-10^{4} \mathrm{CFU} / \mathrm{g}$ total aerobic mesophilic bacteria, $10-10^{4} \mathrm{CFU} / \mathrm{g}$ coliform bacteria, $10^{2}-10^{4} \mathrm{CFU} / \mathrm{g}$ Enterobactericiae, $10^{4} \mathrm{CFU} / g$ E. coli, $10^{4} \mathrm{CFU} / \mathrm{g}$ Staphylococcus (Yentür et al., 1989; Temelli et al., 2002; Hampikyan et al., 2008; Kara et al., 1999; Kilıc, 2016). Hampikyan et al. (2008) also indicated that addition of spices into kokorec enormously increased the number of bacteria in kokorec. Several studies confirmed that spices in Turkey contained high numbers of microorganisms (Karapinar \& Tuncel, 1986; Aksu et al., 1997; Wassouf, 2014). According the results of the studies, following cooking process did not sufficiently diminish microbial load added with spices. Detected Enterococcus as an indicator microorganism at the level of $10^{2}-10^{5} \mathrm{CFU} / \mathrm{g}$ in cooked kokorec confirmed this assumption. In addition, $25 \%$ of cooked products was found being positive for coagulase-positive Staphylococcus, which might create potential hazards for public health. However, the cross contamination with person's hands, knife or other equipment as well as spices had an important role for the prevalence of this microorganisms producing heat stable toxins (Banwart, 1989; Bergdoll, 1989). In these studies, researcher also observed that cooked kokorec stayed on the edge of grill far from the fire effect to be served when the number of costumers was not many or in especially street vendors whole raw kokorec parts were sitting on the edge of grills at the warm conditions until it was cooked, which might generate available environment for the growth of the pathogens. They were also observed that remained part of raw kokorec at the first day was cooked and served in the next day. Detected high number of bacteria load in raw kokorec showed that intestines used for kokorec production might not be cleaned sufficiently and microbiological quality of intestines was found as being very low. In order to eliminate the potential risk of foodborne outbreak associated with consuming kokorec, it is concluded that during preparation steps intestines should be cleaned well, washed and boiled for necessary, kokorec should be consumed at the same day it is cooked and finally proper personal hygiene should be followed.

Official reporting system of foodborne outbreaks has been just establishing in recent years by Turkish Government. Due to insufficient published data regarding outbreaks in Turkey, safety risk of kokorec consuming could not be analyzed. However, some outbreak cases associated with kokorec consuming was unofficially reported in some newspaper without any occurred symptom details (HaberTürk Spor, 2015).

\subsection{Doner kebab}

Doner kebab is one of the traditional products and commonly manufactured with red meat. Doner kebab has been described as the origin of other Mediterranean and Middle Eastern dishes such as shawarma and gyros. In the production of doner, meat is seasoned with onion, pepper, tomatoes and some spices. The meat and some animal fats are shredded or ground, then mixed with seasoning materials including tomato sauce, olive oil, lemon juice, vinegar, milk, yogurt and egg and molded to give a cone like shape. Then the mass is refrigerated at $4{ }^{\circ} \mathrm{C}$ for $12 \mathrm{~h}$ to allow the meat and fat particles to stick together. The stack is cooked by charcoal, wood fire, or radiant infrared heat from electric elements or gas fired burners and it is cut into thin slices as it is gradually broiled. Mostly tail fat, tomatoes and onions are placed on the top of the doner stack to keep it moist by juice drops. The doner slices are usually served to the customer on a plate or in bread like sandwiches with herb, salad or dressing (Kayahan \& Welz, 1992; Moeller et al., 1994). In recent years, doner kebab has become a ready-to-eat food product prepared in meat processing plants. In industrial manufacturing, cooked doner kebab is modified packaged in a plastic tray and sold in supermarkets. According to statistic data, doner kebab is consumed per day in Turkey and Germany at approximately 
460 and 300 tons (2.4-3.5 million Euro per year), respectively (Turizm Gazetesi, 2007; Haberbu, 2007).

Microbiological quality of doner kebab depends on a number of factors, such as the quality of raw materials, effectiveness of the cooking process, sanitation of the restaurants, and personal hygiene. Problems will arise depending on the quality grade of raw meat and/or improper processing. Again, if left over doner is rewarmed to serve at the second day will lead even more harmful consequences.

Some microbiological studies showed that the number of total aerobic bacteria, coliform, $S$. aureus, B. cereus, C. perfringens, (26-40\%) L. monocytogenes (18.8\%), E. coli O157:H7 (11\%), Salmonella spp. (40\%), yeasts and molds in doner kebab in Turkey were found in the range of > 2-6 log CFU/g (Acar \& Ciftcioglu, 1997; Uzumcuoglu \& Sahin, 2001; Kayısıglu et al., 2003; Gencer \& Kaya, 2004; Vazgecer et al., 2004; Elmali et al., 2005; Ulukanli et al., 2006). Several studies also investigated the presence of pathogens in raw or cooked doner samples collected in Germany (Jöckel \& Stengel, 1984; Todd et al., 1986; Kruger et al., 1993). According to Jöckel \& Stengel (1984), C. perfringens or Salmonella spp. were isolated in all raw doner samples, but only $10 \%$ of the cooked samples contained C. perfringens. Additionally, Tebbutt (1991) showed 5\% occurrence of C. perfringens in raw doner kebabs. E. coli was isolated in 18 out of 41 doner samples, 9 and 23 of them contained E. coli higher than $10^{3} \mathrm{CFU} / \mathrm{g}$ and $10^{6} \mathrm{CFU} / \mathrm{g}$, respectively. Similarly, Stolle et al. (1993) reported that eight samples of 44 cooked doner samples obtained from different restaurants in Munich/Germany were C. perfringens positive and no Salmonella was detected. However, Todd et al. (1986) investigated 34 doner samples collected from 11 different markets. They reported that the number of $C$. perfringens was less than $10^{4} \mathrm{CFU} / \mathrm{g}$ in spite of inappropriate practices such as abusive storage temperature. The presence of 5.3-6.2 logs CFU/g Staphylococci in $42 \%$ of the doner samples (40) was also reported by Kruger et al. (1993) with no Salmonella spp was isolated in those samples.

High presence of pathogens especially C. perfringens in doner kebab is associated with several reasons. The temperature at the center of the doner kebab during cooking maintaining the optimal temperature range $\left(25-45^{\circ} \mathrm{C}\right)$ for anaerobic pathogen growth is one of the reasons (Kayısıglu et al., 2003; Pexara et al., 2006). Doner are not ideal meat product for heat transfers which depending on composition, shape and size of the product. The initial temperature at the center of the doner remains stable for long time during cooking because of its irregular shape and size. This nature creates a temperature gradient from the center to the peripheral parts of the mass that may allow bacteria to multiply (Todd et al., 1986). So, it may not be possible to destroy pathogenic microorganisms inside the uncooked parts of the doner mass and as well as in the slices cut for the services which may receive insufficient cooking.

Doner kebab is a traditional product and generally produced with beef and/or lamb. However, production of doner from poultry meat is becoming popular because of lower cost; however, there are concerns about poultry doner kebabs for growth of pathogens. It has been reported that chicken doner kebabs have higher aerobic plate counts, psychotropic bacteria counts and coliform counts than the beef doners (Kayisıglu et al., 2003).

A few foodborne outbreaks associated with doner kebab have been issued in several countries as well as in Turkey. During October 1992, in London, 9 foodborne outbreaks were reported associated with consuming doner kebab contaminated with S. Mikawasima. Again, during July 1995, an outbreak of S. Typhimurium DT170 occurred in South Wales, England. A case-control study found that illness was associated with doner kebabs. In 2004, an outbreak associated with consumption of beef doner kebab contaminated with E. coli O157:H7 was also issued in Calgary, Canada (Currie et al., 2007). Another recent outbreak associated with consuming chicken doner in a wedding reception was reported by Karakeçili et al. (2017). In this outbreak, 108 people were poisoned due to $S$. Thyphimirium occurrence in chicken doner. A number of outbreaks due to consumption of doner kebab especially made of chicken were issued in newspaper in every year in Turkey. Nevertheless, no detail information including suspicious contaminants involving in outbreak was archived by The Turkish Government Agencies.

\subsection{Tahin helva and Tahin}

Tahin helva is one of the common traditional deserts consumed in Turkey. It is produced with tahin which is a paste of sesame seeds, and syrup. To produce helva, tahin is mixed with sugar, citric acid, tartaric acid and Saponaria officinalis root extract and the prepared mix is cooked by adding one or more of the flavoring substances such as cacao, hazel-nut, walnut, dried fruits, mastic, vanilla, bergamot, natural essences and milk powder (Turkish Standards Institution, 1977). The major operation involved in the production of tahin helva is shown at Figure 1 (Birer, 1985). Helva is not a risky product in terms of food safety due to involving high temperature cooking $\left(120^{\circ} \mathrm{C}\right)$ and low product water activity (high sugar content). Processing steps would easily eliminate contaminated pathogens coming with ingredients. Post processing contamination during packaging and transport is the major concern for this product safety.

In recent years, helva and tahin have received increasing attention by causing several outbreaks in the World (Food Standart Agency, 2001; Andersson et al., 2001, 2002; Richardson \& Jackson, 2002). In 2001, 27 cases in Sweden and 16 cases of multiresistant DT104 in Australia associated with consumption of tahin and helva imported from Turkey have been reported. In Norway, 29 cases associated with helva have also been reported in 24 independent outbreaks. Twelve of the 29 cases were younger than 15 years. Samples of helva were also found positive for the same strain. Other outbreaks were also reported associated with tahini contaminated with $S$. Bovismorbificans, $S$. Montevideo, $S$. Mbandaka and S. Maassricht in the United States and New Zealand (Centers for Disease Control and Prevention, 2012, 2013; Paine et al., 2014).

After the European Commission distributed an international alert over 150 samples of helva products in the UK have been tested. Only eight samples were found to be positive for $S$. Typhimurium DT104. They also reported that of those that have tested positive, none were on sale in the major retail chains. Another research 


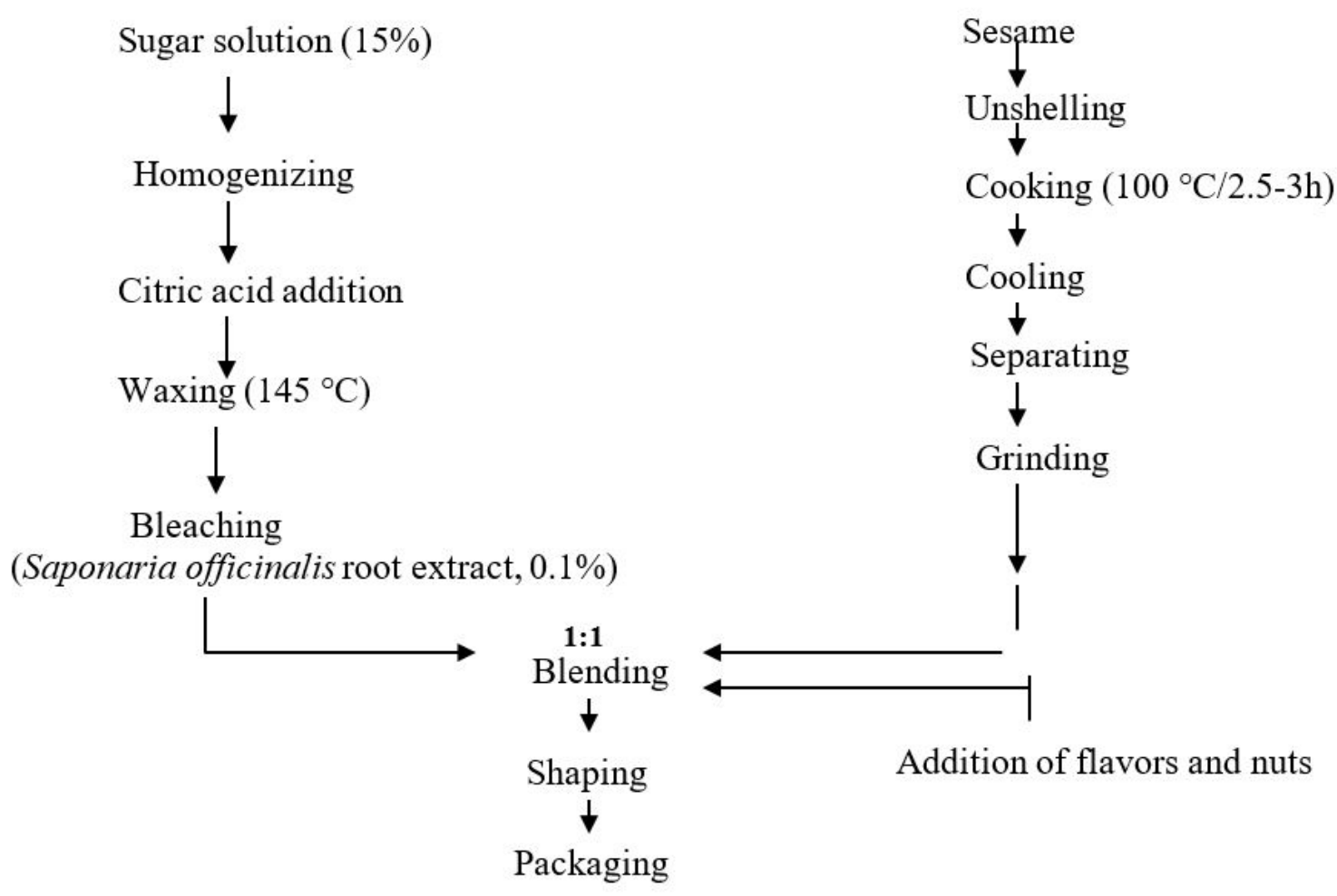

Figure 1. A flowsheet of traditional tahin helva manufacture (Birer, 1985).

group also investigated 117 samples of various sesame seed products bought in local retail and delicatessen stores in southwest Germany (Brockmann et al., 2004). Of these 117 samples, $11(9.4 \%)$ from four different manufacturers were found positive for various strains of multiresistant $S$. Typhimurium DT 104, S. Typhimurium DT 134, Offa, Tennessee, and Poona. Furthermore, the National Enteric Pathogen Surveillance Scheme in Australia has recorded the isolation of 17 different Salmonella spp. from sesame seeds and sesame seed products, including hummus, tahini, and helva between 1985 and 2001 (O'Grady et al., 2001). On the other hand, none of the helva samples (63) collected from the retail markets in Turkey found positive for Salmonella and S. aureus (Sengun et al., 2005). The studies showed that helva may offer a good growth environment for $S$. Enteritidis and S. aureus (Kotzekidou, 1998; Sengun et al., 2005). For example, Kotzekidou (1998) reported that $S$. Enteritidis and S. aureus cells were still recovered after 8 and 9 months of storage at $4{ }^{\circ} \mathrm{C}$ and room temperatures, respectively.

Salmonella contamination of sesame seed seems, therefore, to be a more urgent problem than previously thought. In sesame seed products in which the seed undergoes further treatment or processing, questions about the source of Salmonella contamination arises. Cross-contamination can occur in most cases or in small processing plants in Turkey where minimal standard hygiene conditions are not always maintained during production, but it seems unlikely for several reasons that contamination of sesame seed products occurs regularly during processing.
All these studies demonstrate that products made of sesame seed have potential to lead food poisoning. Thus, its risk must be determined in terms of public health and precautions should be taken. There is a necessity to standardize the process, improve the sanitary conditions and storage of product, and use quality raw materials in helva manufacturing. Therefore, good manufacturing practice and the hazard analysis critical control point (HACCP) concept should minimize such routes of contamination.

\subsection{Turkish white cheese}

Turkish white cheese is classified as soft or semi hard brined cheese. Its taste is characterized as more salty and acidic compared to other cheeses (Hayaloglu et al., 2002). Ripening soft fresh white cheese in brine solution for 3 months generates semi hard texture. White cheese was originally produced from sheep or goat milk, but cow milk or a mixture of milks is now generally used for its production. According to data published in 2001, approximately 243,000 tons of Turkish white cheeses were produced annually, representing 60 to $80 \%$ of the total cheese production in Turkey (Turkey, 2001).

White cheese is usually made from raw milk to obtain a better flavor profile without using starter cultures in small dairies or some large cheese factories (Turantaş et al., 1989; Erkmen, 1995, 1996). Turkish White cheese is not usually produced under mechanized or artisanal conditions and is handled at various stages of manufacture. Thus, various types of microorganisms may enter the cheese during manufacture and subsequent handling as well as transferring from unpasteurized milk (Turantaş et al., 
1989). A number of studies indicated the presence of various pathogens including S. aureus, E. coli O157:H7 L. monocytogenes, Brucella spp., S. Thyphimirium, Y. enterocolitica in white cheese samples (Table 1) (Akbulut et al., 1993; Gonca \& Kilic, 2000; Öksüz et al., 2004; Gokmen et al., 2016). For example; L. monocytogenes was isolated from 3-13.4\% of commercial Turkish White Cheeses collected from two different cities in Turkey (Kara et al., 1999; Gonca \& Kilic, 2000).

Based on the studies, using starter cultures, the natural presence of lactic acid bacteria and ripening process of white cheese in brine solution eliminate some pathogen species including Brucella, Y. enterocolitica and Campylobacter jejuni coming from raw milk or contaminated during manufacturing (Hayaloglu et al., 2002). Moreover, the numbers of $Y$. enterocolitica and S. aureus increase during cheese manufacturing but decrease during the later stages of ripening (Erkmen, 1995, 1996). They stated that inhibition of pathogens during ripening were dependent on salt occurrence, starter activity and. However, $S$. Typhimurium, S. aureus, L. monocytogenes or E. coli in white cheese can show resistance against brine solution or the activity of the starter culture (Erkmen, 1995, 1996; Arici et al., 1999). For example; Arici et al. (1999) stated that L. monocytogenes originating from white cheese survived during 20 weeks of ripening at $4{ }^{\circ} \mathrm{C}$. Erkmen $(2000,2001)$ also reported that L. monocytogenes survived during white cheese manufacture and ripening and might persist for at least 3 months in cheese stored at $4{ }^{\circ} \mathrm{C}$.

Using of starter cultures or natural lactic acid bacteria occurrence in cheese also affects survival of pathogens. The composition of the lactic acid bacterial flora in white cheese was investigated by Karakus et al. (1992). At the beginning of ripening, Lc. lactis subsp. lactis was the predominant species and enterococci (E. faecalis and E. faecium) were the second most dominant species found in white cheese. Other species of lactic acid bacteria including $L b$. casei, $L b$. plantarum, Lb. fermentum, Lb. brevis, Leuconostoc lactis and Leu. mesenteroides subsp. dextranicum were also reported. Lactococci declined during ripening in brine solution, while Lactobacillus species including $L b$. casei and Lb. plantarum was increasing. Acidification of cheese by the activity of lactic acid bacteria occurs rapidly but their action can be limited by increasing salt concentration. Karakus \& Alperden (1992) reported that white cheeses obtained from three different plants contained species of Enterococcus, Staphylococcus, Micrococcus and Coliform bacteria at various levels. Throughout ripening, the number of Enterococcus remained relatively constant while counts of coliform, Staphylococcus and Micrococcus decreased. The microflora of the cheese produced at the same factory can vary depending on various factors. Uraz \& Gundogan (1998), who studied 132 samples of commercial white cheese during a ripening period of 10 weeks, found Bacillus, Lactobacillus, Leuconostoc, Pediococcus, Staphylococcus aureus and coliform bacteria in all samples. Generally, Lactobacillus, Leuconostoc, Pediococcus and Streptococcus are the dominant microorganisms present during storage and grow to higher numbers than other groups of microorganisms. Akbulut et al. (1993) also investigated the survival of some pathogens in white cheese made with or without a starter culture. Results showed the presence of high numbers (3.04-3.38 logs CFU/g) of coliforms and (2.90-3.23 logs $\mathrm{CFU} / \mathrm{g}$ ) and extremely high numbers (5.28-5.45 logs CFU/g) of $E$. coli in cheese made with or without a starter culture at the end of the 90-day ripening period. However, Akbulut et al. (1993) reported that Y. enterocolitica and C. jejuni were killed completely by the addition of starter culture and ripening process.

Fresh cheeses made from unpasteurized milk are also known as the major source of Brucella in Turkey (Cetinkaya et al., 2005; Cengiz, 2007). In 2008, 238 brucellosis cases were reported by the Turkish Ministry of Health (Buzgan et al., 2010). The studies analyzed the fate of Brucella in fresh cheeses produced in several region of Turkey reported mostly positives results for Brucella occurrence (Mert, 1984; Patir \& Dincoglu, 2001; Kalender et al., 2001; Kasimoğlu, 2002; Alim \& Tomul, 2005; Kilic-Altun et al., 2017). For example, Brucella spp. were isolated from $20.5 \%$ of 78 fresh cheese samples collected from 3 cities in Turkey with 81.3 and $18.7 \%$ of them were determined as B. melitensis and B. abortus, respectively (Kalender et al., 2001). In a similar study, $16.6 \%$ cheese samples were found as positive for Brucella collected in 2015 in Urfa, Turkey, (Kilic-Altun et al., 2017). These results showed the importance of pasteurization of milk before manufacturing the cheese and the ripening of white cheeses before marketing. According to pilot studies, Turkish consumers are not adequately acknowledge about the food safety risk of eating fresh white cheese obtained from bazaar (Cagri-Mehmetoglu, 2009). The small cheese producers (40\%) also resisted not to pasteurize milk before making cheese although they knew about the risk of cheese produced from raw milk since the cheese made from heated milk possessing low sensory properties (Yuce \& Alp-Cavus, 2006). Therefore, consuming fresh white cheese made from unpasteurized milk very risky could result brucellosis.

White cheese is also the high potential source of aflatoxin among dairy products in Turkey because aflatoxin M1 (AFM1) is being associated with the casein fraction in milk is somewhat concentrated in cheese (Galvano et al., 1996; Tekinşen \& Tekinşen, 2005; Isleyici et al., 2015). The studies showed that the concentration of AFM1 was about 3 fold higher in many soft cheeses and about 5 fold higher in hard cheeses than the milk (Prandini et al., 2009). The cheeses were manufactured from the milk of animals fed with the feeds which had probably contained performed aflatoxins and/or been contaminated with the spores of Aspergillus spp. Tekinşen \& Tekinşen (2005) determined AFM1 in $31(62 \%)$ of 50 white brined cheese samples. The results are mostly similar to the results of the other studies (Seyrek, 2001; Sarımehmetoglu et al., 2004; Kamkar, 2006; Baskaya et al., 2006; Ardic et al., 2009) but contradict with those of some researchers (Gurbuz et al., 1999; Kaniou-Grigoriadou et al., 2005) who did not observe AFM1 at detectable amounts. These differences may be attributable to the fact that milk to be processed may contain 
different levels of AFM1 according to the seasonal changes (Bakirci, 2001; Galvano et al., 1996) and different analytical methods and processing technique (Pittet, 1998). In addition, the AFM1 level in the milk was significantly affected by the geographical region where cheese is produced (Galvano et al., 1996). In conclusion, AFM1 common contaminant of white brined cheese and can be considered to be a main concern for public health. Therefore, public health authorities should urgently pay attention to AFM1 particularly by monitoring dairy products and informing dairy producers.

\subsection{Stuffed mussel (midye dolma)}

Stuffed mussel, made from mussel and rice, cooked separately then put together in the mussel shell, is generally sold by street vendors in Turkey. It is consumed with lemon juice and eaten by hand. Black mussel (Mytilus galloprovincialis) is mostly used for preparation of stuffed mussels. In the production of stuffed mussels, mussel shells are cleaned well by scraping with a knife, and any beards are removed. A prepared mixture of rice, vegetable oil, salt, and spices is stuffed into each shell, including mussel flesh, and shells are closed tightly before cooking by steaming. Vegetable oil is sprayed on the shells of stuffed mussels to make them shiny.

Familiarity, taste, low-cost, and convenience are some of the appealing factors that make stuffed shell sold in street popular as food source, but they may also present risks to people's health (Tinker, 1997). The safety of stuffed shell is affected by several common factors, from the microbiological quality of the raw materials to food handling and storage practices (Table 1). Stuffed shell sold in street might be exposed to environmental conditions, such as the presence of insects, flies, and dust. Moreover, most street food vendors pay no attention to good food handling practices, exposing foods to unsafe conditions, such as cross-contamination, unhygienic storage, and poor time-temperature conditions (Ekanem, 1998; Kişla \& Uzgun 2008). Generally, mobile street food sellers and stationary food sellers sell the stuffed mussels on a table by the sidewalks. The stuffed mussel sellers carry out their operations in the ambient conditions for 6 to $8 \mathrm{~h}$ or more each day. The consumer uses the mussel shell itself as a spoon to take the stuffing out of the shell and scoop it to the mouth. In this case, the shell of the stuffed mussel is the critical control point for the potential health risk in addition to the stuffing in the shell. Moreover, leftover stuffed mussels are generally taken home at the end of each day and stored at room temperature, or sometimes in the refrigerator until the next day.

Stuffed mussel is an important source of microorganisms especially pathogen bacteria because of preparation and serving process. The microbiological quality of stuffed mussels sold in Turkey has been studied by only a few researchers (Tatlisu, 2002; Colakoglu et al., 2003; Bingol et al., 2008; Kişla \& Uzgun, 2008; Ates et al., 2011; Kök et al., 2015). During the period of MarchOctober 2006, a total of 168 stuffed mussel samples were collected randomly from restaurants, buffets and street sellers located in Istanbul and analyzed some microbiological parameters by a research group (Bingol et al., 2008). Their results showed that
Coliform bacteria were detected at $77.38 \%$, Escherichia coli at $22.02 \%$, S. aureus at $23.80 \%$, B. cereus at $38.69 \%$, yeast and molds at $87.50 \%$ and sulfite-reducing anaerobe bacteria at $36.30 \%$ of stuffed mussel samples, respectively. No Salmonella spp. was detected in analyzed samples. In another study, 5 of the 50 stuffed mussel samples were found to be positive for occurrence of L. monocytogenes (Goksoy et al., 1996). Furthermore, the microbiological quality of not only the stuffing mixture, but also the outer surface of the stuffed mussels was evaluated for 1 year, and the effect of season on the prevalence and the number of the microorganisms were evaluated by Kişla \& Uzgun (2008). The prevalence and the count levels of coliforms, fecal coliforms, Enterobacteriaceae, and Vibrio spp in the samples in summer time were considerably higher compared with those in winter time. Fecal contamination was detected in $40 \%$ of each stuffing mixture and outer surface samples. In total, $14 \%$ of stuffing mixture samples analyzed contained fecal coliforms greater than 3.15 logs MPN/g. Enterobacteriaceae was detected in $40 \%$ and $60 \%$ of stuffing mixture samples, and $32 \%$ and $60 \%$ of outer surface samples in summer and winter time, respectively. The highest count (7.08 logs CFU/g) was observed in one stuffing mixture sample in winter. The frequencies of contamination by coagulasepositive S. aureus were $30 \%$ and $96 \%$ of the samples analyzed in winter and summer time, respectively, with the averages of $2.84 \operatorname{logs} \mathrm{CFU} / \mathrm{g}$. B. cereus was also detected in $28 \%$ of stuffing mixture samples in winter time, whereas it was present in $76 \%$ of stuffing mixture samples in warmer months with averages of 2.94 logs CFU/g. Vibrio spp. was detected in $16 \%$ of stuffing mixture samples in cold months, and in $40 \%$ of the samples in warm months.

Fresh lemon juice and lemon dressing containing citric acid are used as flavoring and acidifying solutions before consuming stuffed mussels in Turkey. A study investigated the antimicrobial activity of fresh lemon juice on $S$. Typhimurium inoculated in a real food system, stuffing mixture of stuffed mussels, with different inoculation levels (Kişla, 2007). The $\mathrm{pH}$ of stuffed mussels was measured as 6.57 . When it was treated with lemon juice and lemon dressing, the $\mathrm{pH}$ of the mixture decreased to 3.63 and 3.78, respectively. Results of the study showed that both lemon juice and lemon dressing used as flavoring and acidifying agents for stuffed mussels caused slight decrease in $S$. Typhimurium as an immediate inhibitor. However, treatment of stuffed mussels with lemon juice up to $15 \mathrm{~min}$ was not enough to kill $S$. Typhimurium in stuffed mussels.

Based on the high bacterial levels and the prevalence of foodborne pathogens, the quality and the safety of the stuffed mussels analyzed were unacceptable for human consumption. The outer surface of the stuffed mussels in addition to the stuffing mixture also might constitute a potential health hazard, depending on the contamination level and lack of sanitary practices, because the shell is used as a spoon by the consumers. As a control measure, it could be suggested that street vendors might sell the stuffed mussels in a cooler, especially in warm seasons. Primarily, it is important that there is a need to enforce regulations on sanitary practices during preparation and sale 
of stuffed mussels through the education of the street vendors (covering their heads, wearing aprons, avoiding handling stuffed mussels and money simultaneously, or handling stuffed mussels with bare hands, etc.), employing the hazard analysis critical control point system as a strategy to prevent contamination.

\section{Risk assessment}

Documentation and risk assessment of risky traditional Turkish Dishes was the main purpose of this review. All risk factors regarding the related dishes were used to assess and estimate the risk for consumer safety. Raw meat ball, kokorec, meat and chicken doner, tahin helva, and white cheese were identified as traditional Turkish dishes leading possible safety problems. Six typical scenarios for consumption of these products based on regions and income were described using related survey data (Wikipedia, 2011). Typical serving size of traditional Turkish dishes was shown on Table 2. Generally, 100-150 g food per portion is consumed (Turkey, 2005a, b; Avocado Bravado, 2011).

Risk factors were categorized ( 1 to 3 ) based on several criteria to estimate degree of risk associated with the prevalence of foodborne pathogens in the dishes (Table 3). The criteria considered on this process were listed as "pathogen prevalence in ingredients", "heat treatment", "raw components in ready-to-eat portion, cross contamination", "g food/portion" and "frequency of consumption".

According to magnified risk factors (Table 3), the traditional Turkish dishes were categorized on Table 4. Risk estimation (categorization) for each dish was made by as well considering six different frequency of consumption scenarios based on statistical data shown on Table 2 (Omurtag et al., 2013). Risk degrees were stated by color, the darker the color the greater the risk for easy analysis. It is apparent that in Western Turkey (Sc 1 and 2), regardless of income, poultry and meat doner, kokorec and midye dolma are foods with main risk for foodborne disease, where in Eastern Turkey (Sc 5), in specific raw meat ball and kokorec, are most related. Additionally, according to the assessment, fresh white cheese was considered as an unsafe food due to low frequency. of consumption. Helva also carry lower risk comparing to other traditional foods in only for people in Eastern Turkey due to higher comcumption.

Table 2. Traditional food consumption in Turkey: Six different scenarios were identified according to statistical data.

\begin{tabular}{|c|c|c|c|c|c|c|c|c|c|c|}
\hline $\begin{array}{l}\text { Scenario } \\
\text { (Sc.) }\end{array}$ & Region & In-come & $\begin{array}{c}\text { Kg red meat } \\
\text { doner/yr/ } \\
\text { person }^{*}\end{array}$ & $\begin{array}{c}\text { Kg poultry } \\
\text { doner /year/ } \\
\text { person* }\end{array}$ & $\begin{array}{l}\text { Kg Kokoreç/ } \\
\text { year/person }\end{array}$ & $\begin{array}{c}\text { Kg raw meat } \\
\text { ball/year/ } \\
\text { person }\end{array}$ & $\begin{array}{c}\text { Kg stuffed } \\
\text { mussel/year/ } \\
\text { person }\end{array}$ & $\begin{array}{c}\mathrm{Kg} \text { fresh } \\
\text { white } \\
\text { cheese/year/ } \\
\text { person }\end{array}$ & $\begin{array}{l}\text { Kg tahin } \\
\text { helva/year/ } \\
\text { person }\end{array}$ & $\begin{array}{l}\text { Equaling } \mathrm{x} \\
\text { serving }\end{array}$ \\
\hline 2 & & Low & 0.68 & 0.45 & 0.002 & 0.1 & 0.4 & 1.2 & 1.5 & $1 /$ month \\
\hline 3 & $\mathrm{C}$ & High & 0.72 & 0.52 & 0.001 & 0.1 & 0.02 & 1.7 & 2.3 & 1/week \\
\hline 4 & & Low & 0.45 & 0.32 & 0.001 & 0.05 & 0.01 & 1.4 & 1.9 & $1 /$ month \\
\hline 6 & & Low & 0.55 & 0.35 & 0.002 & 2.2 & 0.005 & 1.2 & 2.7 & $1 /$ month \\
\hline
\end{tabular}

Region ... East (E)/Central (C)/West (W); ${ }^{*} \ldots$ median.

Table 3. Factors considered in the estimation of the risk magnitude of foodborne pathogens (Omurtag et al., 2013).

\begin{tabular}{cccccc}
\hline Group & $\begin{array}{c}\text { Pathogens occurrence in } \\
\text { raw materials }\end{array}$ & Heating process & $\begin{array}{c}\text { Raw portion in ready-to-eat serving, i.e. } \\
\text { possible cross-contamination }\end{array}$ & g food/serving & Consumption rate \\
\hline 1 & Low $<5 \%$ & Adequate & No & $<50$ & $1 /$ month and fewer \\
2 & Medium $5-50 \%$ & Grill/Barbecue & Yes & $50-150$ & $1 /$ week \\
3 & High $>50 \%$ & Uncooked & Yes & $>150$ & $1-3 /$ week \\
\hline
\end{tabular}

Table 4. Categorization of typical Turkish dishes according to risk factors for foodborne pathogens.

\begin{tabular}{|c|c|c|c|c|c|c|c|c|c|c|}
\hline \multirow[b]{2}{*}{ Food Type } & \multirow{2}{*}{$\begin{array}{c}\text { Occurrence of } \\
\text { pathogens in } \\
\text { food } \\
(1 / 2 / 3)\end{array}$} & \multirow[b]{2}{*}{$\begin{array}{c}\text { Heating } \\
\text { process } \\
(1 / 2 / 3)\end{array}$} & \multirow{2}{*}{$\begin{array}{l}\text { Serving includes } \\
\text { other raw or } \\
\text { ready to eat food } \\
\text { components }(1 / 3)\end{array}$} & \multirow{2}{*}{$\begin{array}{c}\text { Cross- } \\
\text { contamination g } \\
\text { /food serving } \\
(1 / 2 / 3)\end{array}$} & \multicolumn{6}{|c|}{ Frequency of consumption scenarios (Sc) } \\
\hline & & & & & Sc. 1 & Sc. 2 & Sc. 3 & Sc. 4 & Sc. 5 & Sc.6 \\
\hline Kokorec & 2 & 2 & 1 & 3 & & & & & & \\
\hline Meat Doner & 2 & 2 & 3 & 2 & & & & & & \\
\hline Chicken Doner & 3 & 2 & 3 & 2 & & & & & & \\
\hline Fresh white cheese & 3 & 1 & 1 & 2 & & & & & & \\
\hline Tahin helva & 1 & 1 & 1 & 2 & & & & & & \\
\hline
\end{tabular}

Sc.: Scenarios from Table 2. 


\section{Conclusions}

The root of Turkish cuisine composing of one of the richest food cultures in the World reaches through Middle Asia region. Rich table concept which synthesized from all cultures and traditions of people lived in Anatolia was formed by settling down of Turks in Anatolia. Data and information by means of determination, registration and standardization of traditional foods are extremely insufficient to support continuation of production or increasing opportunity to be produced commercially. Accordingly, The Turkish Ministry of Agriculture started a project to collect information about all traditional food products in Turkey in 2004. The long term objectives of the project are to prevent their imitations, to determine food safety regulation for these products, to introduce them to industry and to provide contribution to national income by obtaining their patents. With this project so far 459 traditional foods were informed. Moreover, in the recent years, the projects by government agencies regarding food safety regulations of traditional foods has been accelerated towards qualifying for whole membership of European Union. Standardization about food safety and processing of the most of the traditional foods produced in industrial base was completed. However, since the small food processing plants and restaurants producing the traditional foods still can possibly ignore sanitation and hygiene rules, which might create risk for public health. As well as unsafe production, traditional foods without packaging especially white cheese, helva produced by the small plants were illegally sold on open counters in bazaars in Turkey. The products open for microbiological contamination and growth might become very dangerous for consumption. As long as food controllers often visit food manufacturing plants and bazaars to control whether they follow regulations, no risk will be left regarding food safety.

\section{References}

Acar, M. S., \& Ciftcioglu, G. (1997). Investigation of microbiological content of doner Kebabs manufactured with beef and chicken meat. Journal of Istanbul University Veterinary Faculty, 23, 395-404.

Akbulut, N., Kinik, O., \& Kavas, G. (1993). A study on the survival fate of some pathogens in white pickled cheese. Ege Üniversitesi Ziraat Fakültesi Dergisi, 30, 111-118.

Aksu, H., Bostan, K., \& Ergün, O. (1997). Incidence of Bacillus cereus in processed spices and herbs sold in Turkey. In Proceedings of the 12th the World Congress on Food Hygiene. Rome: AGRIS.

Albayrak, M., Taşdan, K., \& Albayrak, K. (2013). Reflections of commercialization concerns on traditional foods. In Proceedings of the 2nd International Symposium onTraditional Foods from Adriatic to Caucasus. Macedonia: Namık Kemal Üniversitesi.

Alim, A., \& Tomul, Z. D. (2005). Investigation of Brucella in the fresh cheese samples sold at the bazaars of district in Sivas Center, Turkey. Mikrobiyoloji Bulteni, 39(2), 219-223. PMid:16128034.

Andersson,, Y., Jong, B., Hellstrom, L., Stamer, U., Wollin, R., \& Giesecke, J. (2001). Salmonella typhimurium outbreak in Sweeden from contaminated jars of helva (or helva). Eurosurveillance Weekly, 5, 010719. Retrieved from http://www.eurosurveillance.org/ViewArticle. aspx?ArticleId=1715

Andersson, Y., O’Gray, K. A., Alvseike, O., Brockmann, S., Little, C., Esel, D., Stamer, U., Powling, J., Lindstedt, B. A., Surman, S., \& Jong, B. (2002). Multiresistant Salmonella Typhimurium DT 104: an international outbreak. In Proceedings of the International Symposium Salmonella and Salmonellosis. Ploufragan, France.

Ardic, M., Karakaya, Y., Atasever, M., \& Adiguzel, G. (2009). Aflatoxin M1 levels of Turkish white brined cheese. Food Control, 20(3), 196199. http://dx.doi.org/10.1016/j.foodcont.2008.04.003.

Arici, M., Demirci, M., \& Gunduz, H. H. (1999). Listeria monocytegenes' in inek ve koyun sutunden yapilan Beyaz peynirlerin imalat, olgunlasma ve depolama asamalarindaki durumu. Turkish Journal of Agriculture and Forestry, 23, 1133-1137.

Arslan, A., Guven, A., Saltan, S., \& Patir, B. (1992). The microbiological quality of raw meat balls in Elazig. Firat Univerisity Journal of Health Science, 6, 13-18.

Ates, M., Ozkizilcik, A., \& Tabakoglu, C. (2011). Microbiological analysis of stuffed mussels sold in the streets. Indian Journal of Microbiology, 51(3), 350-354. http://dx.doi.org/10.1007/s12088011-0174-6. PMid:22754015.

Avocado Bravado. (2011). Chicken breast pudding (Tavuk gögsü). Retrieved from http://avocadobravado.net/2010/05/03/tavuk-gogsuchicken-breast-pudding/

Bakirci, I. (2001). A study on the occurrence of aflatoxin M1 in milk and milk products produced in Van province of Turkey. Food Control, 12(1), 47-51. http://dx.doi.org/10.1016/S0956-7135(00)00020-7.

Banwart, G. J. (1989). Basic food microbiology (2nd ed.). New York: Avi Book Coopertaion.

Baskaya, R., Aydin, A., Yildiz, A., \& Bostan, K. (2006). Aflatoxin M1 levels of some cheese varieties in Turkey. Medycyna Weterynaryjna, $62,778-780$

Bergdoll, M. S. (1989). Staphylococcus aureus. In M. P. Doyle (Ed.), Foodborne bacterial pathogens (pp. 463-523). New York: Marcel Decker.

Bingol, E. B., Colak, H., Hampikyan, H., \& Muratoglu, K. (2008). The microbiological quality of stuffed mussels (Midye Dolma) sold in Istanbul. British Food Journal, 110(11), 1079-1087. http://dx.doi. org/10.1108/00070700810917992.

Birer, S. (1985). Tahin Helvasının Yapılışı ve Beslenmemizdeki Yeri. Gida, 10, 133-135.

Brockmann, S. O., Piechotowski, I., \& Kimmig, P. (2004). Salmonella in sesame seed products. Journal of Food Protection, 67(1), 178-180. http://dx.doi.org/10.4315/0362-028X-67.1.178. PMid:14717370.

Buzgan, T., Karahocagil, M. K., Irmak, H., Baran, A. I., Karsen, H., Evirgen, O., \& Akdeniz, H. (2010). Clinical manifestations and complications in 1028 cases of brucellosis: a retrospective evaluation and review of the literature. International Journal of Infectious Diseases, 14(6), e469-e478. http://dx.doi.org/10.1016/j. ijid.2009.06.031. PMid:19910232.

Cagri-Mehmetoglu, A. (2009). Public perception of food handling practices and food safety in Turkey. Journal of Food Agriculture and Environment, 7(2), 113-116.

Cakir, I. (1991). Determination of Salmonella spp. in the minced raw meats (Master's thesis). Gazi University, Ankara.

Cengiz, M. (2007). Bruselloz: 76 olgunun değerlendirilmesi (Master's thesis). Şişli Hamidiye Etfal Eğitim ve Araştırma Hastanesi, Ankara.

Centers for Disease Control and Prevention - CDC. (2012) Multistate outbreak of Salmonella serotype Bovismorbificans infections associated with hummus and tahini. United States. Retrieved from http://www. cdc.gov/mmwr/preview/mmwrhtml/mm6146a3.htm

Centers for Disease Control and Prevention - CDC. (2013) Salmonella Montevideo and Salmonella Mbandaka infections linked to tahini sesame paste. Retrieved from http://www.cdc.gov/salmonella/ montevideo-tahini-05-13/ 
Cetinkaya, F., Mus, T. E., Cibik, R., Levent, B., \& Gulesen, R. (2012). Assessment of microbiological quality of cig kofte (raw consumed spiced meatball): prevalence and antimicrobial susceptibility of Salmonella. Food Control, 26(1), 15-18. http://dx.doi.org/10.1016/j. foodcont.2012.01.001.

Cetinkaya, Z., Aktepe, O. C., Ciftci, I. H., \& Demirel, R. (2005). Seroprevalance of Human brucellosis in rural area of Western Anatolia, Turkey. Journal of Health, Population and Nutrition, 23(2), 137-141. PMid:16117365.

Colakoglu, F. A., Cardak, M., \& Cakır, F. (2003). An investigation on microbiological quality of stuffed mussels sold in Canakkale. Gida, 9, 86-89.

Currie, A., MacDonald, J., Ellis, A., Siushansian, J., Chui, L., Charlebois, M., Peermohamed, M., Everett, D., Fehr, M., \& Ng, L. (2007). Outbreak of Escherichia coli O157: $\mathrm{H} 7$ infections associated with consumption of beef donair. Journal of Food Protection, 70(6), 1483-1488. http:// dx.doi.org/10.4315/0362-028X-70.6.1483. PMid:17612080.

Delikanlı, B., Sönmez, B., \& Ozdemir, Y. (2014). Bursa merkezinde tüketime sunulan etsiz çiğ köftelerin mikrobiyolojik kalitesi. Harran Üniversitesi Veteriner Fakültesi Dergisi, 3(1), 13-17.

Durmaz, H., Sagun, E., Sancak, H., \& Sagdic, O. (2007). The fate of two Listeria monocytogenes serotypes in "cig kofte" at different storage temperatures. Meat Science, 76(1), 123-127. http://dx.doi. org/10.1016/j.meatsci.2006.10.020. PMid:22064198.

Ekanem, E. O. (1998). The street food trade in Africa: safety and socioenvironmental issues. Food Control, 9(4), 211-215. http://dx.doi. org/10.1016/S0956-7135(97)00085-6.

Elmali, M., Ulukanli, Z., Tuzcu, M., Yaman, H., \& Cavli, P. (2005). Microbiological quality of beef doner kebabs in Turkey. Archiv fur Lebensmittelhygiene, 56, 32-34.

Erdoğrul, Ö., Erb $\mathrm{l}_{\mathrm{i}}$ r, F., \& Toroğlu, S. (2006). Survival of acid-adapted and non-adapted Staphylococcus aureus in various food samples. Annals of Microbiology, 56(1), 25-27. http://dx.doi.org/10.1007/ BF03174965.

Erginkaya, Z., Songül, Y., Çetindağ, M., \& Güngör, Ö. (2014). Sonuç Bildirgesi. In Proceedings of the IV Geleneksel Gidalar Sempozyumu. Adana. Retrieved from http://www.gidamo.org.tr/resimler/ekler/ ef4171027db1325_ek.pdf

Erkmen, O. (1995). Behavior of Staphylococcus aureus in Turkish Feta cheese during manufacture and ripening. Journal of Food Protection, 58(11), 1201-1205. http://dx.doi.org/10.4315/0362-028X-58.11.1201.

Erkmen, O. (1996). Survival of virulent Yersinia enterocolitica during the manufacture and storage of Turkish Feta cheese. International Journal of Food Microbiology, 33(2-3), 285-292. http://dx.doi. org/10.1016/0168-1605(96)01156-7. PMid:8930712.

Erkmen, O. (2000). Inactivation kinetics of Listeria monocytogenes in Turkish White cheese during the ripening period. Journal of Food Engineering, 46(2), 127-131. http://dx.doi.org/10.1016/S02608774(00)00076-5.

Erkmen, O. (2001). Survival of Listeria monocytogenes during the manufacture and ripening of Turkish White cheese. Die Nahrung, 45(1), 55-58. http://dx.doi.org/10.1002/1521-3803(20010101)45:1<55::AIDFOOD55>3.0.CO;2-Q. PMid:11253643.

Erkmen, O., \& Bozoğlu, T. F. (2016). Food microbiology principles into practice: microorganisms in food preservation and processing (Vol. 2). Chichester: John Wiley and Sons. http://dx.doi.org/10.1002/9781119237860.

Food Standart Agency - FSA. (2001). Some helva products found to be contaminated with Salmonella. Retrieved from http://www.food. gov.uk/news/pressreleases/2001/aug/helva
Galvano, F., Galofaro, V., \& Galvano, G. (1996). Occurence and stability of aflatoxin M1 in milk and milk products: a worldwide review. Journal of Food Protection, 59(10), 1079-1090. http://dx.doi. org/10.4315/0362-028X-59.10.1079.

Gencer, V. K., \& Kaya, M. (2004). Microbiological quality and chemical composition of the doner. Turkish Journal of Veterinary and Animal Sciences, 28, 1097-1103.

Ghazzi, M., Porto-Fett, A. C. S., Ayaz, N. D., Ozansoy, G., Çufaoğlu, G., Goncuoglu, M., Dluzneski, A., Holinka, S., Shoyer, B. A., Shane, L. E., Stahler, L. J., Campano, S. G., \& Luchansky, J. B. (2018). Microbiological characterization of çiğ köfte sold at retail in Ankara, Turkey, and evaluation of selected antimicrobials as ingredients to control foodborne pathogens in çiğ köfte during refrigerated storage. Food Control, 84, 138-147. http://dx.doi.org/10.1016/j. foodcont.2017.04.033.

Gokmen, M., Akkaya, L., Kara, R., \& Onen, A. (2016). Prevalence of Salmonella spp. and L. monocytogenes in some ready to eat foods sold retail in Balıkesir. Van Veterinary Journal, 27(1), 31-36.

Goksoy, E. O., Kirkan, S., \& Kaya, O. (1996). Comparison of polymerase chain reaction and conventional methods for the diagnosis of Listeria monocytogenes in stuffed mussels. Turkish Journal of Veterinary and Animal Sciences, 30, 229-234.

Göktan, D., \& Tuncel, G. (1988). Effect of ingredients on quantitative recovery of Salmonella in raw meat balls. Meat Science, 22(2), 155-160. http://dx.doi.org/10.1016/0309-1740(88)90089-7. PMid:22055245.

Gonca, S., \& Kilic, S. (2000). Investigation of Listeria monocytogenes in Feta cheese. Ege Üniversitesi Ziraat Fakültesi Dergisi, 37, 105-111.

Guran, S.., \& Oksuztepe, G. (2014). Effects of chitosan and some essential oils (thyme, clove, roemary), individually or in combination, on inactivation of Salmonella Typhimutium in çiğ köfte (Turkish raw meatball). Firat Üniversitesi Sağlık Bilimleri Dergisi, 28, 117-122.

Gurbuz, U., Nizamlioglu, M., Nizamlioglu, F., Dinc, A., \& Dogruer, Y. (1999). Investigation of aflatoxin in some meat and dairy products and spices. Veterinarium, 10, 34-41.

Guven, A., Gulmez, M., \& Kamber, U. (1997). Investigations of some pathogenic bacteria and determination of the microbiologic quality of minced meat sold in Kars city. Kafkas University Veterinary Faculty Journal, 3, 57-65.

Haberbu. (2007). Döner kebab overhauls hamburger in Europe! Retrieved from http://www.haberbu.com/haber_detay.php?id=15993

HaberTürk Spor. (2015). Kokoreç yüzünden maç iptal edildi. Retrieved from http://haber.stargundem.com/spor/1515733-kokoreczehirlenmesi-maci-iptalettirdi.html

Hampikyan, H., Ulusoy, B., Bingöl, E. B., Colak, H., \& Akhan, M. (2008). Determination of microbiological quality of some grilled food, salad and appetizers. Türk Mikrobiyoloji Cemiyeti Dergisi, 38, 87-94.

Hayaloglu, A. A., Guven, M., \& Fox, P. F. (2002). Microbiological, biochemical and technological properties of Turkish White cheese 'Beyaz Peynir'. International Dairy Journal, 12(8), 635-648. http:// dx.doi.org/10.1016/S0958-6946(02)00055-9.

Isleyici, O., Sancak, Y. C., Sagun, E., \& Ekici, K. (2006). Listeria species in Cig Kofte. The Indian Veterinary Journal, 83, 1023-1024.

Isleyici, O., Sancak, Y. C., Sancak, H., \& Yucel, U. M. (2015). Ambalajsız olarak satışa sunulan çiğ inek sütlerinde aflatoksin M1 düzeyinin belirlenmesi. Van Veterinery Journal, 26(3), 151-155.

Jöckel, J., \& Stengel, G. (1984). Doner Kebab-Untersuchung und Beurteilung einer Turkischen Spezialitat. Die Fleischwirtschaft, 64, 527-540.

Kalender, H., Ozcan, C., \& Arslan, N. (2001). Taze tulum peynirlerinden Brucella izolasyonu. Türk Mikrobiyoloji Cemiyeti Dergisi, 31, 184-186. 
Kamkar, A. (2006). A study on the occurrence of aflatoxin M 1 in Iranian Feta Cheese. Food Control, 17(10), 768-775. http://dx.doi. org/10.1016/j.foodcont.2005.04.018.

Kaniou-Grigoriadou, I., Eleftheriadou, A., Mouratidou, T., \& Katikou, P. (2005). Determination of aflatoxin $M_{1}$ in ewe's milk samples and the produced curd and Fetacheese. Food Control, 16(3), 257-261. http://dx.doi.org/10.1016/j.foodcont.2004.03.003.

Kara, A. A., Algur, O. F., \& Kaya, M. (1999). Investigation on the Isolation and identification of the listeria species in the white and civil cheeses purchased from Erzurum region. Turkish Journal of Biology, 23, 331-337.

Karakeçili, F., Çıkman, A., \& Karagöz, A. (2017). Bir dügüun yemeği sırasında gıda kaynaklı Salmonella typhimurium salgını. Klimik Dergisi/Klimik Journal, 30(3), 131-135. http://dx.doi.org/10.5152/ kd.2017.32.

Karakus, M., \& Alperden, I. (1992). Changing in microbiological and chemical properties of white cheese during maturation. Gida Sanayi, 6, 34-47.

Karakus, M., Borcakli, M., \& Alperden, I. (1992). Lactic acid bacteria during the maturation of white cheese. Gida, 17, 363-369.

Karapınar, M., \& Tuncel, G. (1986). Microbiological quality of spices sold at retail markets. E.U. Mühendislik Fakültesi Dergisi, Seri B, 4, 27-36.

Karlıkaya, G., Çiftçi, B., Bulut, H., \& Cihat, T. (2005). Neurotrichinosis: a case report from Turkey. Journal of the Neurological Sciences, 22, 75-78.

Kasimoğlu, A. (2002). Determination of Brucella spp. in raw milk and Turkish white cheese in Kirikkale. DTW. Deutsche Tierarztliche Wochenschrift, 109(7), 324-326. PMid:12161972.

Kayahan, M., \& Welz, W. (1992). Zur ueblichkeit der spezialitaet doener kebap Erhebungen in Bremen. Archiv fur Lebensmittelhygiene, 43, 143-144.

Kayısıglu, S., Yilmaz, I., Demirci, M., \& Yetim, H. (2003). Chemical composition and microbiological quality of the doner kebabs sold in Tekirdag market. Food Control, 14(7), 469-474. http://dx.doi. org/10.1016/S0956-7135(02)00103-2.

Kilıc, B. (2016). Determination of microbiological quality of kokoreç sold in Isparta. Scientific Papers: Series D, Animal Science, 59, 216-221.

Kilic-Altun, S., Yiğin, A., Gürbilek, S. E., Gürbüz, S., Demirci, M., Keskin, O., \& Tel, O. Y. (2017). An enzyme-linked immunosorbent assay for Brucella specific antibody Klimik Dergisi, and real-time PCR for detecting Brucella Spp. in milk and cheese in Şanlıurfa, Turkey. Pakistan Veterinary Journal, 37(1), 39-42.

Kimiran-Erdem, A., Saglam, D., Ozer, D., \& Ozcelik, E. (2014). Microbiological quality of minced meat samples marketed in Istanbul. YYU Veteriner Fakultesi Dergisi, 25(3), 67-70.

Kişla, D. (2007). Effectiveness of lemon juice in the elimination of Salmonella Typhimurium in stuffed mussels. Journal of Food Protection, 70(12), 2847-2850. http://dx.doi.org/10.4315/0362028X-70.12.2847. PMid:18095441.

Kișla, D., \& Uzgun, Y. (2008). Microbiological evaluation of stuffed mussels. Journal of Food Protection, 71(3), 616-620. http://dx.doi. org/10.4315/0362-028X-71.3.616. PMid:18389710.

Kök, F., Şahiner, C., Koçak, P., Göksoy, E. Ö., Beyaz, D., \& Büyükyörük, S. (2015). Determination of microbiological quality of stuffed mussels sold in Aydin and İzmir. MANAS Journal of Engineering, 3(1), 70-76.

Kotzekidou, P. (1998). Microbiological stability and fate of Salmonella enteritidis in helva, a low-moisture confection. Journal of Food Protection, 61(2), 181-185. http://dx.doi.org/10.4315/0362028X-61.2.181. PMid:9708278.
Kruger, J., Schulz, V., \& Kuntzer, J. (1993). Doner kebab-Unterschungenzum Handelsbrauch in Stuttgart. Die Fleischwirtschaft, 73, 1242-1248.

Kuplulu, O., Sarimehmetoglu, B., \& Oral, N. (2003). The microbiological quality of cig kofte sold in Ankara. Turkish Journal of Veterinary and Animal Sciences, 27, 325-329.

Mert, A. (1984). Ankara yöresinde pazarlanan taze beyaz peynirlerde Brucella’ların varlığı üzerinde araştırmalar ( $\mathrm{PhD}$ dissertation). Ankara University, Health Science Institute, Ankara.

Moeller, B., Flechsig, I., Buettner, M., \& Schiefer, G. (1994). Food hygiene aspects of monitoring trade in Doner kebab. Fleisch, 48, 22-24.

Ocal, M. H. (1997). Properties of raw meat ball (158 p.). Şanlıurfa: Ozlem Press.

O'Grady, K. A., Powling, J., Tan, A., Valcanis, M., Lightfoot, D., Gregory, J., Lalor, K., Guy, R., Ingle, B., Andrews, R., Crerar, S., \& Stafford, R. (2001). Salmonella Typhimuriun DT104 - Australia. Europe. No. 20010822.1980. Retrieved from www.promedmail.org

Öksüz, O., Arici, M., Kurultay, S., \& Gumus, T. (2004). Incidence of Escherichia coli $\mathrm{O} 157$ in raw milk and white pickled cheese manufactured from raw milk in Turkey. Food Control, 15(6), 453456. http://dx.doi.org/10.1016/S0956-7135(03)00121-X.

Omurtag, I., Paulsen, P., Hilbert, F., \& Smulders, F. J. M. (2013). Demographic/socio-economic factors and dietary habits determining consumer exposure to foodborne bacterial hazards in Turkey through the consumption of meat. Food Security, 5(1), 103-115. http://dx.doi. org/10.1007/s12571-012-0231-y.

Paine, S., Thornley, C., Wilson, M., Dufour, M., Sexton, K., Miller, J., King, G., Bell, S., Bandaranayake, D., \& Mackereth, G. (2014). An outbreak of multiple serotypes of Salmonella in New Zealand linked to consumption of contaminated tahini imported from Turkey. Foodborne Pathogens and Disease, 11(11), 887-892. http://dx.doi. org/10.1089/fpd.2014.1773. PMid:25393669.

Patir, B., \& Dincoglu, A. H. (2001). Studies on the existence of Brucella spp. in fresh White cheese and Tulum cheese marketed in Elazığ. FU Saglik Bilgileri Veterinerlik Dergisi, 15(1), 15-22.

Pekel, C., Var, I., Kabak, B., Sener, A., \& Burcu, O. (2003). The microbiological quality of raw meat balls. In Proceedings of the 1st Regional Students of Food Engineering-conference (pp. 1-6). Adana, Turkey.

Pexara, A., Ambrosiadis, I., Georgakis, S., \& Genigeorgis, K. (2006). A new production technology for "gyros": evaluation of parameters affecting the quality of the final product. Journal of Food Engineering, 77(3), 601-609. http://dx.doi.org/10.1016/j.jfoodeng.2005.07.019.

Pittet, A. (1998). Natural occurrence of mycotoxins in foods and feeds an updated review. Revue de Medecine Veterinaire, 149, 479-492.

Prandini, A., Tansini, G., Sigolo, S., Filippi, L., Laporta, M., \& Piva, G. (2009). On theoccurrence of aflatoxin M1 in milk and dairy products. Food and Chemical Toxicology, 47(5), 984-991. http:// dx.doi.org/10.1016/j.fct.2007.10.005. PMid:18037552.

Richardson, K., \& Jackson, R. (2002). A bulletin for the Australian Food Industry. Australia: Food Safety and Hygiene. Retrieved from http:// www.foodscience.csiro.au/fshbull/fshbull29b.htm

Sagun, E., Alisarli, M., \& Durmaz, H. (2003). The effect of different storage temperatures on the growth and enterotoxin producing characteristics of Staphylococcus aureus in cig kofte. Turkish Journal of Veterinary and Animal Sciences, 27, 839-845.

Sagun, E., Sancak, Y. C., Durmaz, H., \& Ekici, K. (1997a). Microbiological quality of some species used in foods. Yuzuncu Yil University Journal of Health Sciences, 8, 1-5. 
Sagun, E., Sancak, Y. C., Durmaz, H., \& Akkaya, L. (1997b). A study on hygienic quality of raw meat balls consumed in Van. Yuzuncu Yil University Journal of Health Sciences, 3, 64-67.

Sancak, Y. C., Boynukara, B., \& Agaoglu, S. (1993). The microbiological quality of ground-meat marketed in Van. Yüzüncü Yll Üniversitesi Veteriner Fakültesi Dergisi, 4, 73-76.

Sarımehmetoglu, B., Kuplulu, O., \& Haluk Celik, T. (2004). Detection of aflatoxin M1 in cheese samples by ELISA. Food Control, 15(1), 45-49. http://dx.doi.org/10.1016/S0956-7135(03)00006-9.

Sengun, I. Y., Hancioglu, O., \& Karapinar, M. (2005). Microbiological profile of helvasold at retail markets in Izmir city and the survival of Staphylococcus aureus in this product. Food Control, 16(10), 840844. http://dx.doi.org/10.1016/j.foodcont.2004.07.005.

Seyrek, K. (2001). Determination Aflatoxin M1 level in white cheese consumed in Turkish Troop by ELISA technique. Veteriner Hekimler Dernegi Dergisi, 72, 55-58.

Stolle, A., Eisgruber, H., Kerschhofer, D., \& Kraube, G. (1993). Doner kebab untersuchungen zur verkehrsauffassung und mikrobiologischhygienischen Beschaffenheit im Raum München. Die Fleischwirtschaft, 73, 938-948.

Tatlisu, N. U. (2002). Determination of quality of the stuffed mussels sold in Istanbul markets (Master's thesis). Faculty of Fisheries, Natural Science Institute, Istanbul University, Istanbul.

Tebbutt, G. M. (1991). Assessment of hygiene risks in premises selling takeaway foods. Environmental Health, 99, 97-100.

Tekinșen, K. K., \& Tekinşen, O. C. (2005). Aflatoxin M1 in white pickle and Van otlu (herb) cheeses consumed in southeastern Turkey. Food Control, 16(7), 565-568. http://dx.doi.org/10.1016/j. foodcont.2004.02.006.

Temelli, S., Saltan-Evrensel, S., Anar, S., \& Tayar, M. (2002). Determinatıon of the microbiological quality of kokoreç Samples consumed in Bursa. Journal Faculty of Veterinary Medicine of Istanbul University, 28(2), 467-473.

Tinker, I. (1997). Street foods: urban food and employment in developing countries. New York: Oxford University Press.

Todd, E. C. D., Szabo, R., \& Spiring, F. (1986). Donairs (Gyros)-potential hazards and control. Journal of Food Protection, 49(5), 369-377. http://dx.doi.org/10.4315/0362-028X-49.5.369.

Turantaş, F., Ünlütürk, A., \& Göktan, D. (1989). Microbiological and compositional status of Turkish White cheese. International Journal of Food Microbiology, 8(1), 19-24. http://dx.doi.org/10.1016/01681605(89)90076-7. PMid:2701567.

Turizm Gazetesi. (2007). Do Germans eat döner kebab everytime? Retrieved from http://www.turizmgazetesi.com/article.aspx?id=23426

Turkey. (2001). Sekizinci bes yıllık kalkınma planı gıda sanayii ozel ihtisas komisyonu raporu sut ve sut urunleri sanayii alt komisyon raporu. Ankara. No. DPT:2636-OIK:644.

Turkey, Ministery of Culture and Tourism - MCT. (2005a). Tandir Kebabi. Retrieved from http://www.kultur.gov.tr/EN/belge/2-1088/ tandir-kebab.html

Turkey, Ministery of Culture and Tourism - MCT. (2005b). Shish Kebabi. Retrieved from http://www.kultur.gov.tr/EN/belge/2-1082/ shish-kebab.html
Turkey, National Assembly. (2005c). Directorate of Municipal Police Regulations, 5393 Law on Municipalities and Metropolitan Municipalities Act 5216 came into force. Official Gazette. Retrieved from http://cekmekoy.bel.tr/yazdir.php?q=zabita-mudurlugu

Turkish Standards Institution - TSE. (1977). TS 2590: Turkish Standard of Tahin Helva (pp. 4). Ankara.

Ulukanli, Z., Cavli, P., \& Tuzcu, M. (2006). Detection of Escherichia Coli O157:H7 from beef doner kebabs sold in Kars. G.U. Journal of Science, 19, 99-104.

Uraz, G., \& Gundogan, N. (1998). Beyaz peynirlerin mezofil mikroflorasinda Koliform, Streptokok, LLP (Laktobasil, Lokonostok, Pediokok) Stafilokok ve Basilluslarin Bulunma sikliklari. Gida, 23, 391-401.

Uzumcuoglu, U., \& Sahin, E. (2001). Investigation of döner kebabs sold in Ankara (Master's thesis). Ankara: Department of Food Engineering, Ankara University.

Uzunlu, S., \& Yıldırım, I. (2003). Microbiological quality of raw meat ball and investigation of its microbial variation at the different storage time and temperature. Gida, 28, 553-558.

Uzunlu, S., Yildirim, I., \& Serdengecti, N. (2002). Investigation of microbial quality of raw meat ball which consumed in Antalya, Turkey. In Proceedings of the thirtieth Turkish Microbiology-conference (pp. 273). Antalya, Turkey.

Vazgecer, B., Ulu, H., \& Oztan, A. (2004). Microbiological and chemical qualities of chicken doner kebab retailed on the Turkish restaurants. Food Control, 15(4), 261-264. http://dx.doi.org/10.1016/S09567135(03)00065-3.

Vural, A., Aksu, H., \& Erkan, M. E. (2006). Low-dose irradiation as a measure toImprove microbiological quality of Turkish raw meat ball (cig kofte). International Journal of Food Science \& Technology, 41(9), 1105-1107. http://dx.doi.org/10.1111/j.1365-2621.2006.01273.x.

Wassouf, N. (2014). Açıkta satılan baharatların gerçek zamanlı polimeraz zincir reaksiyonu ile mikrobiyolojik yönden incelenmesi (Lisans tezi). Hacettepe Üniversitesi Fen Bilimleri Enstitüsü Beslenme Bilimleri Yüksek, Ankara.

Wikipedia. (2011). Türk mutfağı. Retrieved from http://tr.wikipedia. org/wiki/T\%C3\%BCrk_mutfa\%C4\%9F\%C4\%B1\#Et_yemekleri

Yentür, G., Abbasoglu, U., \& Bayhan, A. (1989). Research on the microbiological qualities of kokoreç consumed in Ankara. Gazi Üniversitesi Eczacilik Fakultesi Dergisi, 6, 12-15.

Yıldırım, I., Uzunlu, S., \& Topuz, A. (2005). Effect of gamma irradiation on some principle microbiological and chemical quality parameters of raw Turkish meat ball. Food Control, 16(4), 363-367. http://dx.doi. org/10.1016/j.foodcont.2004.04.001.

Yuce, A., \& Alp-Cavus, S. (2006). Brucellosis in Turkey. Klimik Dergisi, 19, 87-97.

Yücel, N., Çıtak, S., \& Onder, M. (2005). Prevalence and antibiotic resistance of Listeria species in meat products in Ankara, Turkey. Food Microbiology, 22(2-3), 241-245. http://dx.doi.org/10.1016/j. fm.2004.03.007. 